\title{
Kemampuan Berpikir Kritis Peserta Didik Melalui Model Pembelajaran Guided Inquiry Berbasis Riset Berbantuan Media WhatsApp
}

\author{
Siti Nur Annisa ${ }^{1)^{*}}$, Setiono ${ }^{1)}$, Aa Juhanda ${ }^{1)}$ \\ ${ }^{1)}$ Universitas Muhammadiyah Sukabumi \\ “sitinurannisa799@gmail.com
}

Abstrak: Penelitian ini bertujuan untuk menganalisis kemampuan berpikir kritis peserta didik SMP pada pembelajaran daring setelah penerapan model guided inquiry berbasis riset berbentuan media whtasApp pada materi interkasi makhluk hidup dengan lingkungan. Subjek penelitian adalah siswa kelas VII dari salah satu SMP di kabupaten Sukabumi dengan sample 33 orang peserta didik. Metode penelitian yang digunakan adalah pre experimental design. Desain penelitian yang digunakan adalah one-group pretest posttest design dengan teknik pengambilan sampel Purposive sampling. Instrumen yang digunakan adalah soal tes kemampuan berpikir kritis berupa pilihan ganda sebanyak 23 soal dengan 5 indikator kemampuan berpikir kritis. Data hasil penelitian menunjukan pembelajaran menggunakan model guided inquiry berbasis riset berbantuan media whatsApp dapat melatihkan kemampuan berpikir kritis siswa yang terlihat dari adanya peningkatan dari hasil pretest dan postets yang menunjukkan kategori cukup, baik dan sangat baik. Rata- rata persentase ketercapaian kemampuan berpikir kritis peserta didik yaitu 79\% termasuk dalam kategori baik, Serta kemampuan berpikir kritis yang dicapai peserta didik laki- laki lebih unggul dari perempuan. Hal ini menunjukan dalam pembelajaran daring SMP pada materi interaksi makhluk hidup dengan lingkungan menggunakan model pembelajaran guided inquiry berbasis riset berbantuan media whatsApp dapat meningkatkan kemampuan berpikir kritis peserta didik dan berguna untuk keberlangsungan proses pembelajaran.

Kata Kunci: Berpikir kritis, Guided inquiry berbasis riset, media whatsApp

\section{Pendahuluan}

Pendidikan merupakan sebuah pondasi dalam kehidupan yang harus dibangun dengan sebaik- baiknya. Secara umum pendidikan merupakan proses pembelajaran pengetahuan, keterampilan, serta kebiasaan yang di lakukan suatu individu dari satu generasi ke generasi lainnya (Ramdhani, 2020). Visi pendidikan Indonesia pada tahun 2035 adalah membangun rakyat Indonesia untuk menjadi pembelajar seumur hidup yang unggul, terus berkembang, sejahtera dan berakhlak mulia dengan menumbuhkan nilai- nilai budaya Indonesia dan Pancasila (Kemendikbud, 2020). Namun Pandemik COVID-19 yang melanda Indoneisa mengaharuskan sejak Maret 2020 saluruh satuan pendidikan di Indonesia melakukan program pembelajaran jarak jauh atau sering disebut pembelajaran daring. Pebelajaran jarak jauh tersebut diberlakukan dalam rangka menghambat penyebaran COVID-19. Selama pembelajaran daring guru jarang melaksanakan praktikum terlebih untuk materi tertentu dengan alat dan bahan yang sulit didapatkan serta kurangnya semangat peserta didik. Keterbatasan guru dan peserta didik dalam mengelola pembelajaran daring menyebabkan menurunya kemampuan serta keterampilan yang dimiliki peserta didik.

Mencapai tujuan dan visi dari pendidikan di Indonesia serta untuk berkompetisi dalam menghadapi abad21 harus di kembangkannya kemampuan peserta didik. Kemampuan yang harus di miliki peserta didik salah satunya yaitu berpikir kritis, suatu kemampuan penting yang harus di miliki peserta didik untuk menghadapi tantangan pada abad 21. Critical thingking is reasonable and reflective thingking focused on decing what to believe or do (Ennis, 2015), yang artinya berpikir kritis adalah suatu proses berpikir reflective yang berfokus pada memutuskan apa yang diyakini atau dilakukan. Perkembangan zaman modern dan teknologi yang canggih pada saat ini informasi sangatlah menyebar dengan cepat maka dari itu penting bagi peserta didik memiliki kemampuan berpikir kritis agar dapat mengolah dan memproses suatu informasi yang baik dan benar. Berpikir kritis 
memungkinkan pembaca untuk menilai bukti terhadap apa yang dibaca dan dapat mengidentifikasi penalaran palsu atau tidak logis. Berpikir kritis juga membantu untuk membuat argumen yang kuat (Zakiah \& Lestari, 2019).Kemampuan berpikir kritis memiliki peranan dalam kehidupan global di abad 21 (Beni et al., 2019). Faktanya kemampuan berpikir kritis masih kurang di kembangkan pada pendidikan di Indonesia. Melihat hasil studi PISA 2018 di bidang sains menempatkan indonesia pada peringkat rendah yaitu ke 9 dari bawah (71) dengan rata-rata skor 396.

Untuk meningkatkan kemampuan berpikir kritis peserta didik diperlukan adanya suatu model pembelajaran yang dapat melatih kemampuan berpikir kritis peserta didik yaitu model pembelajaran guided inquiry berbasis riset. Suatu model pembelajaran yang dapat dijadikan alternatif pada saat pembelajaran daring. Penggunaan model ini membuat peserta didik dapat tetap melakukan eksperimen dalam proses pembelajaran walaupun dalam keadaan pembelajaran jarak jauh. Peserta didik dapat melalui proses pembelajaran yang bermakna dan dapat mengeksplore, dan membangun pengetahuannya sendiri melalui penerapan model pembelajaran guided inquiry berbasis riset ini. Inquiry merupakan pembelajaran yang direkomendasikan dalam pengejaran sains, matematika, bahasa, dan ilmu sosial (Setiono et al., 2020). Inkuiri juga dikenal sebagai seluruh proses atau kegiatan yang digunakan para ilmuwan saat melakukan proses ilmiah, dan cara yang berkaitan dengan pencarian makna sains sebenarnya (Ulva et al., 2017). Pembelajaran Inkuiri merupakan pembelajaran dengan serangkaian kegiatan yang melibatkan seluruh kemampuan peserta didik secara sistematis, kritis, dan logis agar dapat menemukan sendiri sebuah pengetahuan (Rohmah, 2019). Guided inquiry berbasis riset merupakan pembelajaran yang memposisikan peserta didik untuk menyelesaikan permasalahan dengan tahapan pengajuan hipotesis, pengumpulan data, pengujian hipotesis melalui data yang di kumpulkan dan menarik kesimpulan dari proses pembelajaran yang telah dilaksanakan.

Untuk menunjang pembelajaran daring bagi peserta didik diperlukan sebuah inovasi media komunikasi yang mudah di akses oleh peserta didik itu sendiri, salah satunya dengan menggunakan apliksi whatsApp. WhatsApp (WA) dimanfaatkan untuk berkomunikasi dan menyampaikan pesan kepada seseorang yang akan dituju. Informasi yang akan di sampaikan akan lebih efektif, karena penggunaan aplikasi whatsApp mudah dan lebih cepat di terima oleh sasarannya (Salam, 2020). Dengan aplikasi whatsApp memungkinkan penggunanya untuk berbagi berbagai konten dan lain sebagainya dalam proses pembelajaran. Media whatsApp dipilih untuk membantu implementasi pembelajaran dengan model guided inquiry berbasis riset melalui pembelajaran jarak jauh (PJJ) karena ditinjau dari posisi banyaknya pengguna dan kenyamanan yang dirasakan peserta didik.

Penggunaan model pembelejaran guided inquiry berbasis riset berbantuan media whatsApp dalam penelitian ini adalah untuk mengoptimalkan pembelajaran daring dimasa pnademik covid-19. Terutma untuk pembelajaran praktikum. Tujuan dari penelitian ini untuk mengetahui kemampuan berpikir kritis peserta didik kelas VII SMP dalam pembelajaran daring melalui pembelajaran Guided Inquiry Berbasis Riset Berbantuan Media WhatsApp yang berfokus pada pembelajaran IPA.

\section{Metode}

Metode yang di gunakan dalam penelitian ini adalah pre experimental design dengan rancangan one-group pretest posttesst design, yaitu pengambilan satu kelompok atau kelas yang diberkan pra dan pasca uji. Populasi yang digunakan pada penelitian ini yaitu siswa kelas VII pada salah satu SMP di Kabupaten Sukabumi pada tahun ajaran 2020/2021. Sedangkan sampel yang digunakan sebanyak 33 peserta didik terdiri dari 15 perempuan dan 18 laki-laki yang diperoleh dengan teknik purposive sampling yaitu pengambilan sample yang di dasarkan pada pertimbangan tertentu (Sugiono, 2015). Penelitian dilakukan pada bulan April 2021.

Instrumen soal tes kemampuan berpikir kritis berupa pilihan ganda. Adapun indikator soal tes kemampuan berpikir kritis dapat dilihat pada tabel 1 .

Prosedur penelitian meliputi melaksanakan pembelajaran IPA pada materi interkasi makhluk hidup dengan lingkungan. Sebelum dan setelah pembelajaran selesai peserta didik diberikan soal test pilihan ganda untuk mengukur kemampuan berpikir kritis.

Skor kemampuan berpikir kritis diuji yaitu dengan uji deskriptif statistik dengan program SPSS, dan juga hasil yang diperoleh kemudian dianalisis berdasarkan capaian rata- rata skor kemampuan berpikir kritis peserta didik perindikator dengan rumus: 


$$
\text { Persentase Skor siswa }=\frac{\text { skor prolehan }}{\text { skor maksimal }} \times 100 \%
$$

Kemudian dihitung rata-rata persentase skor total peserta didik dengan rumus:

$$
\text { Rata }- \text { rata }=\frac{\sum \text { persentase }}{\sum \text { siswa }}
$$

Kemudian dihitung N-Gain dari rata-rata Skor perindikator, dengan rumus:

$$
\mathrm{N}-\mathrm{Gain}=\frac{\text { skor } \text { posttest }- \text { skor } \text { pretest }}{\text { skor ideal-skor pretest }}
$$

Kemudian di lakukan analisis kemampuan berpikir kritis berdasarkan gender serta perncapaian gender di setiap indikator kemampuan berpikir kritis.

Adapun kategori presentae kemampuan berpikir kritis di interpretasikan menurut (Sugiono, 2015).

\begin{tabular}{|c|c|c|c|c|}
\hline No & Indikator & Sub-Indikator & No Soal & $\sum$ \\
\hline 1 & $\begin{array}{l}\text { Memberikan } \\
\text { penjelasan sederhana } \\
\text { (Elementari clarification) }\end{array}$ & $\begin{array}{l}\text { - Memfokuskan pertayaan } \\
\text { - Menganalisis argumen } \\
\text { - Bertanya dan menjawab pernyataan klarifikasi dan } \\
\text { pernyataan yang menantang }\end{array}$ & $\begin{array}{l}8 \\
1,9,19 \\
10\end{array}$ & 5 \\
\hline 2 & $\begin{array}{l}\text { Membangun } \\
\text { keterampilan dasar } \\
\text { (basic support) }\end{array}$ & $\begin{array}{l}\text { - Mempertimbangkan kreadibilitas suatu sumber dapat } \\
\text { di percaya atau tidak } \\
\text { - Mengobseravsi dan mempertimbangkan hasil } \\
\text { observasi }\end{array}$ & $\begin{array}{l}2,11,22 \\
3,20\end{array}$ & 5 \\
\hline 3 & $\begin{array}{l}\text { Menyimpulkan } \\
\text { (inferensi) }\end{array}$ & $\begin{array}{l}\text { - Membuat induksi dan mempertimbangkan induksi } \\
\text { - Membuat dan mempertimbangkan nilai keputusan } \\
\text { - Membuat dedukasi dan mempertimbangkan hasil } \\
\text { deduksi }\end{array}$ & $\begin{array}{l}12 \\
13 \\
4,14\end{array}$ & 4 \\
\hline 4 & $\begin{array}{l}\text { Membuat penjelasan } \\
\text { lanjut (advenced } \\
\text { clarification) }\end{array}$ & $\begin{array}{l}\text { - Mendefinisikan istilah, mempertimbangkan definisi } \\
\text { - Mengidentifikasi asumsi }\end{array}$ & $\begin{array}{l}5,15,23 \\
21\end{array}$ & 4 \\
\hline 5 & $\begin{array}{l}\text { Strategi dan taktik } \\
\text { (strategies and tactics) }\end{array}$ & $\begin{array}{l}\text { - Memutuskan suatu tindakan } \\
\text { - Berinteraksi dengan orang lain }\end{array}$ & $\begin{array}{l}6,16,17 \\
7,18\end{array}$ & 5 \\
\hline & \multicolumn{3}{|l|}{ Jumlah total pertanyaan } & 23 \\
\hline
\end{tabular}
Kriteria tersebut dapat dilihat pada table2.

Tabel 1. Kisi-kisi soal test kemampuan berpikir kritis

Tabel 2. Persentase Kategori Kemampuan Berpikir Kritis

\begin{tabular}{cc}
\hline Persentase $(\%)$ & Kategori \\
\hline $86 \%-100 \%$ & Sangat Baik \\
$76 \%-85 \%$ & Baik \\
$60 \%-75 \%$ & Cukup \\
$55 \%-59 \%$ & Kurang \\
$\leq 54 \%$ & Kurang Sekali \\
\hline
\end{tabular}

\section{Hasil dan Pembahasan}

Tabel 3. Uji Skor kemampuan Berpikir Kritis

\begin{tabular}{|l|c|c|c|c|c|}
\hline \multicolumn{7}{|c|}{ Descriptive Statistics } \\
\hline & N & Minimum & Maximum & Mean & Std. Deviation \\
\hline Pre-Test & 33 & 17,39 & 82,61 & 47,4309 & I5,8027I \\
\hline Pos-ttest & 33 & 56,52 & 95,65 & 79,4473 & II,04539 \\
\hline Valid N (listwise) & 33 & & & & \\
\hline
\end{tabular}

Kemampuan berpikir kritis merupakan kemampuan yang sangat penting serta dapat berguna dalam semua aspek kehidupan (Ahmatika, 2017). Berpikir kritis dapat di kembangkan dalam pembelajaran dengan 
memperkaya pengalaman peserta didik (Hasnunidah, 2012). Pengalaman yang di bekalkan dapat berupa kesempatan dalam berpendapat secara lisan maupun tulisan layaknya seperti seoang ilmuan (Curto \& T, 2005). Hasil Uji statistik Skor kemampuan berpikir Kritis di sajikan pada tabel 3.

Hasil tes kemampuan berpikir Kritis setiap indikator di sajikan pada tabel 4.

Tabel 4. Hasil Kemampuan Berpikir Kritis Setiap Indikator

\begin{tabular}{cl|cc|c}
\hline \multirow{2}{*}{ No } & \multirow{2}{*}{ Indikator Kemampuan Berpikir Kritis } & \multicolumn{2}{|c}{ Presentase Ketercapaian (\%) } & \multirow{2}{*}{ Kategori } \\
\cline { 3 - 4 } & & Pre-Test & Post-Test & \\
\hline 1 & Memberi penjelasan sederhana (elementary clarification) & $53 \%$ & $87 \%$ & Sangat baik \\
2 & Membangun keterampilan dasar (basic support) & $38 \%$ & $76 \%$ & Baik \\
3 & Menyimpulkan (inferensi) & $61 \%$ & $86 \%$ & Sangat baik \\
4 & Membuat penjelasan lanjut (advenced clarificaation), & $33 \%$ & $65 \%$ & Cukup \\
5 & Strategi dan taktik (strategies and tactics) & $50 \%$ & $81 \%$ & Baik \\
\hline & Rata- Rata & $48 \%$ & $79 \%$ & \\
\hline
\end{tabular}

Hasil kemampuan berpikir kritis pada saat pre-tets memiliki nilai rata- rata $48 \%$ yang termasuk dalam kategori kurang dan terjadi peningkatan pada saat post-test yaitu menjadi 79\% yang termasuk dalam kategori baik. Berdasarkan tabel 3 tersebut dapat dibuat grafik kemampuan berpikir kritis sebagai berikut:

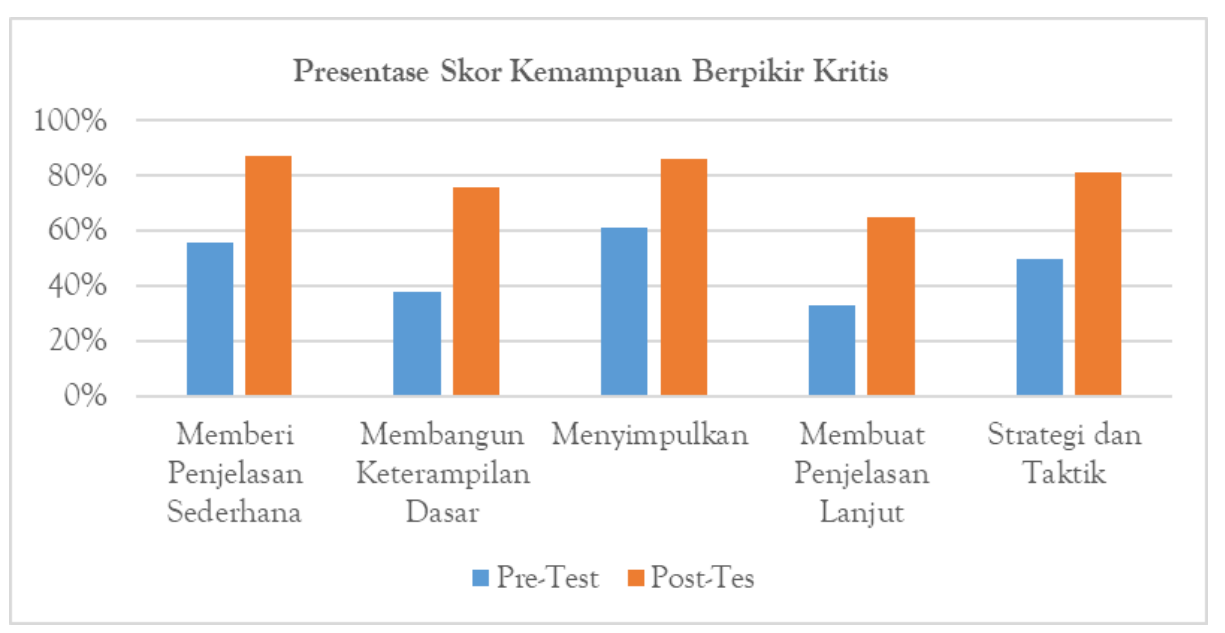

Gambar 1. Presentase Hasil Kemampuan Berpikir Kritis Setiap Indikator

Dari gambar $1 \mathrm{di}$ atas menunjukan bahwa perolehan presentase tertinggi kemampuan berpikir kritis peserta didik terdapat pada indikator 1 dan terendah pada indikator 4 .

Tabel 5. Nilai N-Gain Perindikator

\begin{tabular}{c|cc|c|c}
\hline Indikator & $\begin{array}{c}\text { Skor Rata-rata Berpikir Kritis Setiap Indikator } \\
\text { Pre-Test }\end{array}$ & N-Gain & Kategori \\
\hline 1 & 52,73 & 86,67 & 0,72 & Tinggi \\
2 & 37,58 & 75,76 & 0,61 & Sedang \\
3 & 60,61 & 86,36 & 0,65 & Sedang \\
4 & 33,33 & 65,15 & 0,48 & Sedang \\
5 & 50,30 & 80,61 & 0,61 & Sedang \\
\hline
\end{tabular}

Tabel 5 di atas menunjukan N-Gain skor setiap indikator kemampuan berpikir kritis pada indikator 1 termasuk dalam kategori peningkatan tinggi, dan pada indikator 2, 3, 4 dan 5 termasuk dalam kategori peningkatan sedang.

Gambar 2 menunjukkan garfik kemampampuan berpikir kritis peserta didik laki- laki lebih unggul dari perempuan yaitu dengan presentase sebesar $81 \%$ sedangkan peserta didik perempuan sebesar $78 \%$. 


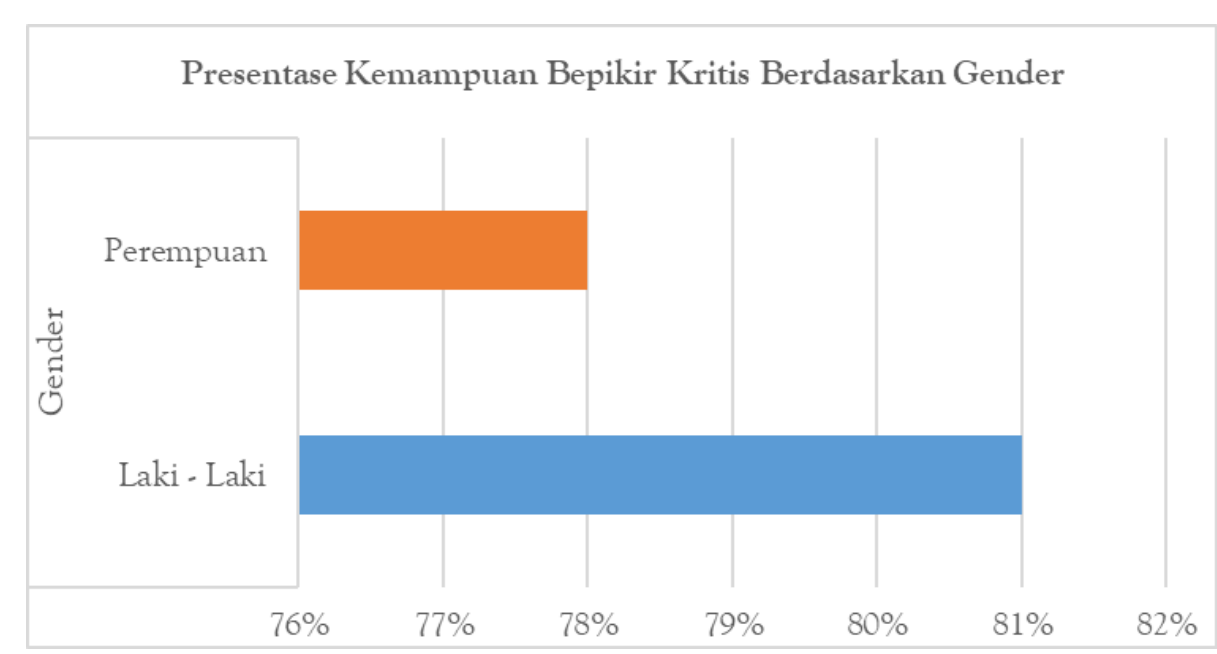

Gambar 2. Presentase Kemampuan Berpikir Kritis Berdasarkan Gender

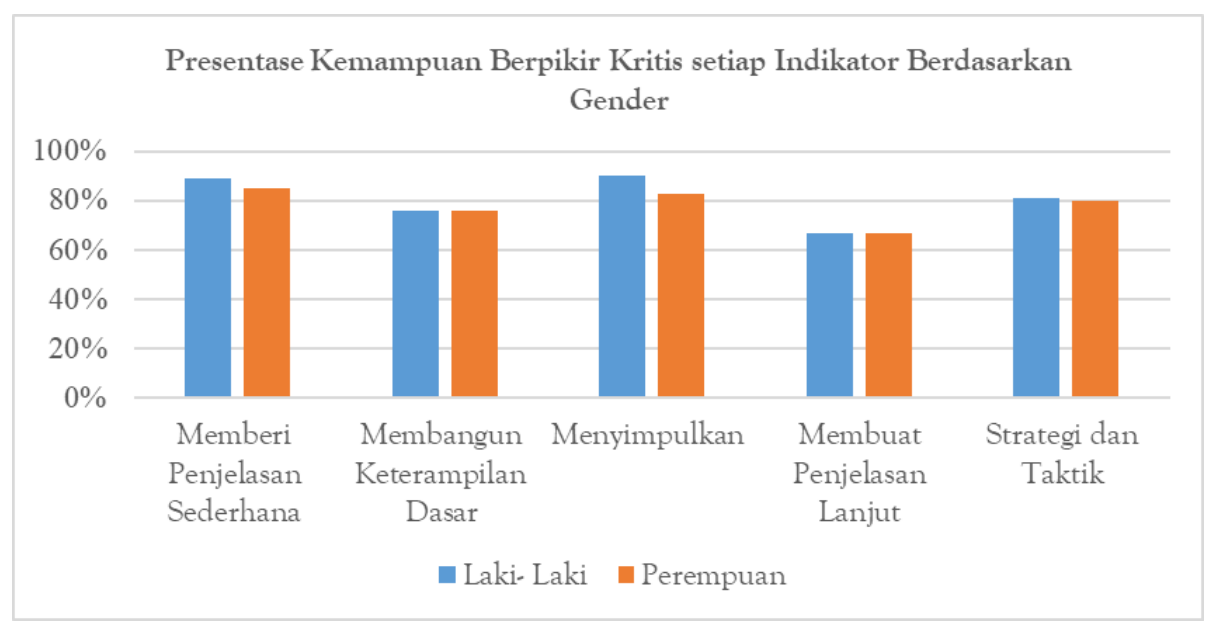

Gambar 3. Presentase Kemampuan Berpikir Kritis Setiap Indikator Berdasarkan Gender

Gambar 3 Merupakan grafik kemampuan berpikir kirtis peserta didik laki- laki dan perempuan setiap indikator, menunjukan bahwa pada indikator 1, 3 dan 5 peserta didik laki- laki lebih unggul dari perempuan dan pada indikator 2, dan 4 peserta didik laki- laki dan perempuan memiliki presentase kemampuan berpikir kritis yang sama.

Hasil Penelitian pada tabel 2 menunjukan uji statistik deskriptif yang memuat nilai maksimum, minumum dan mean. Berdasarkan pada tabel 3 dan gambar pada grafik menunjukkan adanya perbedaan yang signifikan pada skor pre-test dan post-tes. Peserta didik memiliki nilai yang lebih tinggi pada saat post-tes dibandingan dengan nilai pre-test. Hal ini memungkinkan karena pada saat proses pembelajaran berlangsung menggunakan model guided inquiry berbasis riset berbantuan media whatsApp. Peserta didik mendapatkan pengalaman belajar yang bermakna sehingga melatih kemampuan berpikir kritis peserta didik. Melihat grafik pada gambar 1 di atas, perolehan nilai posttest pada indikator 1 yaitu memberi penjelasan sederhana terjadi peningkatan dengan nilai presentase sebesar $87 \%$ yang termasuk kedalam kategori sangat baik, pada indikator 2 yaitu membangun keterampilan dasar terjadi peningkatan dengan nilai presentase sebesar $76 \%$ yang termasuk dalam kategori baik, indikator 3 yaitu menyimpulkan terjadi peningkatan dengan nilai presentase sebesar $86 \%$ yang termasuk dalam kategori baik, indikator 4 memberi penjelasan lanjut terjadi peningkatan dengan nilai presentase sebesar $65 \%$ yang termasuk dalam kategori cukup, dan indikator 5 yaitu strategi dan taktik terjadi peningkatan dengan nilai presentase sebesar $81 \%$ yang termasuk dalam kategori baik. Rata- rata persentase ketercapaian kemampuan berpikir kritis peserta didik yaitu 79\% yang termasuk dalam kategori baik. Hal ini menunjukkan bahwa penerapan model guided inquiry berbasis riset berbantuan media whatsApp memiliki efek positif terhadap kemampuan berpikir kritis peserta didik. Pada indikator 1 yaitu memberikan penjelasan sederhana peserta didik belajar berpikir kritis secara bertahap melalui pertanyaan yang membutuhkan penjelasan belajar melalui kebiasaan- kebiasaan yang di latihkan berupa merumuskan masalah dan menjawab pertanyaan yang 
membutuhkan penjelasan (Thompson, 2011), pada indikator 2 meminta peserta didik untuk mengobseravsi serta mempertimbangkan hasil observasi yang telah di lakukan, pada indikator 3 peserta didik membuat kesimpulan dari sebuah data, keyakinan, pendapat dan lain sebagainya, pada ndikator ke 4 melatih kemampuan mendefinisikan istilah dan mempertimbangkan definisi, serta mengidentifikasi asumsi, sebagian peserta didik sudah mampu namun sebagian yang lain masih belum mampu untuk mengindentifikasi istilah serta mempetimbangkannya sehingga masih dalam kategori cukup, dan pada indikator 5 soal yang di berikan pada indikator ini yaitu kemampuan memutuskan suatu tindakan dan berinteraksi dengan orang lain. Pada tebel 4 menunjukan N-Gain dari setiap indikator, perolehan N-Gain terbesar terdapat pada indikator 1 yaitu dengan nilai 0,72 termasuk kedalam kategori tinggi, lalu pada indikator 3 dengan nilai 0,65 termasuk dalam kategori sedang, indikator 2 dan 5 dengan nilai 0,61 termasuk ke dalam kategori sedang dan indikator 4 dengan nilai 0,48 yang masih termasuk dalam kategori sedang. Pada gambar 2 menunjukan presentase kemampuan berpikir kritis pada peserta didik laki- laki lebih unggul di bandingan dengan peserta didik perempuan walaupun perolehan presentase keduanya yaitu dalam kategori baik. Pada gambar 3 menunjukkan kemampuan berpikir kritis peserta didik laki- laki dan perempuan di setiap indikator. Pada indikator 1 peserta didik laki- laki lebih unggul dengan nilai presentase $89 \%$ termasuk dalam kategori sangat baik dan perempuan memiliki nilai presentase $85 \%$ termasuk dalam kategori baik, karena peserta didik laki- laki realif lebih mampu memberikan alasan penguatan atas jawaban yang di berikannya sehingga skor yang di dapat lebih tinggi. Pada indikator 2 peserta didik laki- laki dan perempuan memiliki nilai presentase yang relatif sama yaitu $76 \%$ termasuk dalam kategori baik, pada indikator 3 peserta didik laki- laki memiliki nilai presentase $90 \%$ termasuk dalam kategori sangat baik dan perempuan memiliki nilai presentase $83 \%$ termasuk dalam kategori baik, pada indikator 4 peserta didik laki- laki dan perempuan memiliki nilai presentase yang relatif sama yaitu $67 \%$ termasuk dalam kategori cukup, pada indikator 5 peserta didik laki- laki memiliki nilai presentase $81 \%$ termasuk dalam kategori baik dan perempuan sebesar $80 \%$ juga termasuk dalam kategori baik.

Proses pembelajaran akan terjadi ketika peserta didik dapat berinteraksi, mengajukan pertanyaanpertanyaan serta mengkonstruksi pengetahuan baru dari pengalaman yang didapat peserta didik dalam kehidupan sehari- hari dan pengetahuan awal peserta didik itu sendiri (Penelitian \& Kunci, 2012). Pembelajaran jarak jauh (PJJ) yang dilakukan dengan model guided inquiry berbasis riset berbantuan apliaksi whatsApp dalam penelitian ini yaitu peserta didik berdiskusi dan berinteraksi serta bertukar pikiran yang di pandu oleh guru secara online, serta mengirim file, foto dan video pembelajaran untuk peserta didik. Melihat hasil penelitian yang menunjukkan bahwa kemampuan berpikir kritis peserta didik laki- laki lebih unggul dari peserta didik perempuan berkaitan dengan proses pembelajarannya yang di lakukan yaitu pertama guru memberikan orientasi sebuah video dan foto mengenai sebuah fenomena mengenai materi yang akan di pelajari, setelah pemberian suatu permasalahan seperti itu lalu peserta didik dapat berdiskusi mengenai permasalahan yang telah dikemukakan, tahap selanjutnya yaitu eksplorasi dimana peserta didik mengusulkan hipotesis lalu merancang dan melakukan praktikum (riset sederhana) secara home based learning sesuai LKPD yang telah diberikan oleh guru, tahap selanjutnya peserta didik mengkontruksi kosep yaitu dimana guru memberikan pertanyaan yang dapat mendorong peserta didik untuk berpikir kritis sehingga peserta didik dapat membangun pengetahuan konsepnya sediri. Tahap selanjutnya adalah aplikasi yaitu setelah konsep diidentifikasi akan di perkuat dan diperluas. Lalu pada tahap aplikasi peserta didik, menggunakan pengetahuan barunya terhadap latihan, suatu masalah atau situasi yang lain dan bahkan pada saat situasi penelitian, tahapan terakhir yaitu penutup dimana peserta didik dapat memvalidasi dan merefleksiakan hasil serta melakukan penilaian terhadap diri sendiri dan menarik sebuah kesimpulan. Setelah semua tahapan selesai peserta didik dapat menjawab soal- soal yang ada di LKPD dan setelah itu di kirimkan kepada guru melalui aplikasi whatsApp. Pada saat proses pembelajaran berlangsung motivasi belajaran peserta didik laki- laki terlihat lebih baik di tunjukkan dengan sikap yang aktif, dan responsif di bandingkan dengan peserta didik perempuan. Ada perbedaan terhadap laki- laki dan perempuan dalam penggunaan otak saat berpikir. Laki- laki cenderung menggunakan otak bagian kanan, sehingga dapat meminimalisir keterlibatan perasaan dan emosi, sementara perempuan menggunakan kedua bagain otaknya sehingga perempuan berpikir lebih menyeluruh dan sering merasa keraguan (Novitasari, 2017). Rasa keraguan yang dapat menyebabkan peserta didik perempuan menjadi kurang tepat dalam menjawab pertanyaan yang diajukan dalam soal berpikir kritis, sehingga perolehan kemampuan berpikir kritis peserta didik laki- laki lebih unggul. Hasil kemampuan berpikir kritis setiap indikator berdasarkan gender ini sejalan dengan (Rodzalan \& M, 2015) yang mengemukakan bahwa kemampuan berpikir kritis dan memecahkan masalah lebih unggul dimiliki oleh seorang laki- laki dibandingkan dengan perempuan. Sama halnya dengan yang di ungkapkan 
(Anom et al., 2018) yang juga mengemukakan bahwa kemampuan memecahkan masalah seorang laki- laki lebih baik apabila dibandingkan dengan perempuan, tetapi kedua gender tersebut memiliki kemampuan yang relatif sama dalam hal berpikir kritis. Kemampuan seorang laki- laki dapat melebihi kemampuan seorang perempuan dalam hal mengobservasi, mengontrol variabel dan menentukan kesimpulan, dan kemampuan perempuan yang dapat melebihi laki- laki yaitu dalam hal conceptual knowledge serta menginterpretasi data (Yamtinah et al., 2017). Pada dasarnya manusia memiliki kemampuan yang berbeda- beda antara satu dengan yang lainnya, namun tidak ada seorangpun yang benar- benar persis bakat, kemampuan serta minat yang di milikinya. Seorang perempuan pada umumnya lebih baik dalam hal mengingat, dan laki- laki lebih baik dalam hal berpikir logis, namun secara umum peserta didik laki- laki sama dengan peserta didik perempuan, akan tetapi peserta didik laki- laki mempunyai daya abstraksi yang lebih baik dari pada perempuan sehingga peserta didik laki- laki dapat lebih baik dibandingkan peserta didik perempuan (Ambarwati et al., 2014).

Ketercapaian pada setiap indikator kemampuan berpikir kritis peserta didik disebabkan oleh model guided inquiry berbantuan media whatsApp, karena model pembelajaran ini merupakan salah satu model inovatif yang dapat meningkatkan kemampuan berpikir kritis peserta didik. Hal yang sama di ungkapkan dalam penelitian (Suana et al., 2019) menunjukan bahwa penerapan model guided inquiry berbantuan media whatsApp dapat meningkatkan kemampuan berpikir kritis peserta didik. Dalam penelitian (Arina et al., 2019) pembelajaran berbasis riset memiliki pengaruh terhadap kemampuan berpikir kritis peserta didik. Pembelajaran guided inquiry berbasis riset ini yaitu mengintegrasikan riset kedalam proses pembelajaran. Dalam pembelajaran guided inquiry berbasis riset, sangat penting untuk menciptakan lingkungan belajar dimana peserta didik dapat memenuhi peran sebagai peneliti dan dapat melakukan penelitian. (Dakker \& Van B, 2017)

Menurut Eniolorunda dalam (Audu et al., 2018) strategi pembelajaran inkuiri terbimbing (GIIS) adalah suatu pendekatan untuk menanyakan dimana guru memimpin muridnya dengan pertanyaan yang dirumuskan dengan baik yang dirancang untuk membawa peserta didik berhadapan dengan pengetahuan yang mereka cari. Strategi inkuiri terbimbing memberi kesempatan peserta didik untuk mengetahui hal- hal sendiri dan gagasan ilmiah melalui mengajukan pertanyaan, investigasi, observasi dan kosntruksi penjelasan yang masuk akal, berbagai informasi serta pengalaman. Peneliti merekomendasikan guided inquiry ini karena sesuai dengan penelitian yang dilakukan oleh (Ardani, 2014) yang menyatakan bahwa penerapan model guided inquiry di respon dengan baik oleh peserta didik, serta meningkatkan keterampilan bepikir kritis siswa. Kemudian, (Solohin, M et al., 2018) menyatakan model inkuiri terbimbing (guided inquiry) berpengaruh signifikan terhadap kemampuan berpikir kritis peserta didik. Penelitian ini dapat di simpulkan bahwa kemampuan berpikir kritis peserta didik dalam kategori baik dengan menerapkan model guided inquiry berbasis riset berbantuan media whatsApp dalam pembelajaran daring.

\section{Simpulan}

Berdasarkan hasil penelitian, dapat disimpulkan bahwa kemampuan berpikir kritis peserta didik pada pembelajaran daring dengan penerapan model guided inquiry berbasis riset berbantuan media whatsApp dalam pembelajaran IPA materi interkasi makhluk hidup dengan lingkungan termasuk dalam kategori baik yaitu dengan presentase $79 \%$. Kemampuan berpikir kritis tertinggi terdapat pada indikator 1 yaitu memberikan penjelasan sederhana dengan perolehan presentase sebesar $87 \%$ dan pencapaian terendah pada indikator 4 yaitu membuat penjelasan lanjut dengan perolehan presentase sebesar $65 \%$. Kemampuan berpikir kritis peserta didik laki- laki lebih unggul dari peserta didik perempuan diamana peserta didik laki-laki memperoleh nilai rata - rata presentase sebesar $81 \%$ sedangakan peserta didik perempuan memperoleh nilai rata- rata presentase sebesar 78\%. Pada indikator 1, 3 dan 5 peserta didik laki- laki lebih unggul dan pada indikator 2 dan 4 peserta didik laki- laki dan perempuan memiliki kemampuan relatif sama. Sehingga penggunaan model ini dapat menjadi pertimbangan peneliti selanjutnya dalam pendidikan IPA

\section{Daftar Pustaka}

Ahmatika, D. (2017). PENINGKATAN KEMAMPUAN BERPIKIR KRITIS SISWA DENGAN PENDEKATAN INQUIRY/DISCOVERY. Euclid, 3(1), 394-403. https://doi.org/10.33603/e.v3i1.324

Ambarwati, M., Mardiyana, M., \& Sri, S. (2014). Profil Proses Berpikir Kritis Siswa Kelas VIII SMP Negeri 3 Surakarta Dalam Memecahkan Masalah Pokok Bahasan Sistem Persamaan Linear Dua Variabel (Spldv) 
Ditinjau Dari Kecerdasan Majemuk Dan Gender. Jurnal Elektronik Pembelajaran Matematika, 2(9).

Anom, K. W., Sukaryawan, M., \& Haryani, M. E. (2018). Jurnal penelitian pendidikan kimia : kajian hasil penelitian pendidikan kimia volume 5, nomor 1, 2018. 5(2015), 57-67.

Ardani, R. (2014). Pengaruh Model Guided Inquiry Berbasis Ekspeimen Terhadap Keterampilan Berpikir Kritis Siswa Pada Materi Fluida Statis Di SMA Negeri 1 Gedangan. Jurnal Inovasi Pendidikan Fisika, 3(2).

Arina, H., Fatimatul, M., Irsad, R., \& Yunin, H. (2019). Peningkatan Keterampilan Berpikir Kritis Siswa Melalui Pendekatan Pembelajaran Berbasis Riset. Jurnal Pendidikan, 2(1).

Audu, C., Ajayi, V. O., \& Angura, T. (2018). Do Guided and Structured Inquiry Instructional Strategies Have Any Comparative Effects on Studentss Achievement in Basic Science and Technology? A Field Report. SSRN Electronic Journal, 8(33), 81-88. https://doi.org/10.2139/ssrn.3069288

Beni, B., Bustami, Y., \& Leliavia, L. (2019). Implementasi Model Pembelajaran Kooperatif Tipe Jirqa Terhadap Kemampuan Berpikir Kritis Siswa Pada Materi Pertumbuhan Dan Perkembangan Tumbuhan. Edubiotik: Jurnal Pendidikan, Biologi Dan Terapan, 4(01), 9-15. https://doi.org/10.33503/ebio.v4i01.308

Curto, K., \& T, B. (2005). Writing and Speaking to Learn Biology: An Intersection of Critical Thingking and Communication Skills. Bioscene: Journal of College Biology Teaching, 31(4).

Dakker, S., \& Van B, N. (2017). Chapter 1. Guide for a project inquiry-based learning.

Ennis, R. H. (2015). The nature of critical thinking: outlines of general critical thinking disposition and abilities. Sixth International Conference on Thinking at MIT, 2013, 1-8.

Hasnunidah, N. (2012). Keterampilan Berpikir Kritis Siswa SMP pada Pembelajaran Ekosistem Berbasis Konstruktivisme Menggunakan Media Maket. Jurnal Pendidikan MIPA, 13(1), 64-74.

Kemendikbud. (2020). Peta Jalan Pendidikan Indonesia 2020-2035.

Novitasari, D. (2017). Analisis Kreativitas Siswa Dalam Pemecahan Masalah Visual Spasial Dan Logis Matematis Ditinjau Dari Gender. Media Pendidikan Matematika, 5(2), 75. https://doi.org/10.33394/mpm.v5i2.1837

Penelitian, A., \& Kunci, K. (2012). INKUIRY LABORATORIUM DAN NILAINYA DALAM PENGAJARAN SAINS Setiono *), Nuryani Y Rustaman **), Adi Rahmat **). 2012-2015.

Ramdhani, N. (2020). Pentingnya Memahami Fungsi dan Tujuan dari Pendidikan.

Rodzalan, S. A., \& M, M. S. (2015). The Perception of critical Thinking and Problem Solving Skill among Malaysian Undergraduate Students. Procedia-Social and Behavioral Sciences, 172, 725-732.

Rohmah, M. (2019). Pengaruh Model Pembelajaran Inkuiri Terbimbing Dengan Media Lingkungan Sekitar Terhadap Keterampilan Berpikir Kritis Materi Ekosistem Siswa SMP Negeri 1 Sukoharjo. Universitas Lampung.

Salam, M. (2020). WhatsApp: Kehadiran, Aktivitas Belajar, dan Hasil Belajar. Jurnal Pendidikan Matematika, 11(2), 198. https://doi.org/10.36709/jpm.v11i2.11675

Setiono, S., Nuranti, G., \& Agustini, M. M. (2020). Meningkatkan Hasil Belajar Peserta Didik Melalui Aktivitas Saintifik Dan Visualisasi. Jurnal Pendidikan Sains (Jps), 8(1), 27. https://doi.org/10.26714/jps.8.1.2020.2731

Solohin, M, W., Sri, Handono, B, P., \& Supeno. (2018). Pengaruh Model Pembelajaran Inkuiri Terbimbing Terhadap Kemampuan Berpikir Kritis Siswa SMA. Jurnal Pembelajaran Fisika, 7(3).

Suana, W., Raviany, M., \& Sesunan, F. (2019). Blended Learning Berbantuan Whatsapp: Pengaruhnya Terhadap Kemampuan Berpikir Kritis Dan Kemampuan Pemecahan Masalah. Gravity: Jurnal Ilmiah Penelitian Dan Pembelajaran Fisika, 5(2), 37-45. https://doi.org/10.30870/gravity.v5i2.4990

Sugiono. (2015). Statistika Untuk Penelitian. Alfabeta.

Thompson, C. (2011). Critical Thinking across the Curriculum: Process over Output. International Journal of Humanities and Social Science, 1(9), p4. 
Ulva, V., Ibrohim, I., \& Sutopo, I. (2017). Mengembangkan Sikap Ilmiah SISWA SMP Melalui Pembelajaran Inkuiri Terbimbing Pada Materi Ekosistem. 2(5).

Yamtinah, S., Masykuri, M., Ashadi, \& Shidiq, A. S. (2017). Gender differences in students' attitudes toward science: An analysis of students' science process skill using testlet instrument. AIP Conference Proceedings, 1868(August). https://doi.org/10.1063/1.4995102

Zakiah, L., \& Lestari, I. (2019). Berpikir Kritis dalam Konteks Pembelajaran. Erzatama Karya Abadi. 